\title{
IT Blueprint for an Effective Online Learning System with a Blended Approach for Upper Secondary Education System During COVID-19 Pandemic
}

\author{
Arief Ramadhan ${ }^{1}$, Satrio Pradono Suryodiningrat ${ }^{2}$, \\ Harco Leslie Hendric Spits Warnars ${ }^{1}$ \\ ${ }^{1}$ Computer Science Department, BINUS Graduate Program - Doctor of Computer Science, \\ Bina Nusantara University, Indonesia \\ ${ }^{2}$ Computer Science, Bina Nusantara University, Jakarta, Indonesia
}

\begin{abstract}
Online learning is becoming the main teaching method since the COVID-19 pandemic. What happens after the pandemic is over? Will the online education be still going? The schools have implemented online learning systems to replace the current teaching methods to ensure the teaching and learning process keeps going. However, research have found that not all students respond well to fully online learning methods, therefore a blended learning system is needed to facilitate the difference in student performance. This IT blueprint will ensure that an upper secondary school is equipped with the proper IT system for its purposes as well as propose blended learning system where the school will apply both online learning and face-to-face teaching method at the same time to maximize student potential.
\end{abstract}

DOI: $10.18421 /$ TEM111-57

https://doi.org/10.18421/TEM111-57

Corresponding author: Arief Ramadhan, Computer Science Department, BINUS Graduate Program - Doctor of Computer Science, Bina Nusantara University, Indonesia.

Email: arief.ramadhan@binus.edu

Received: 31 December 2021.

Revised: 15 February 2022.

Accepted: 21 February 2022.

Published: 28 February 2022.

(c) BY.NC-ND (C) 2022 Arief Ramadhan, Satrio Pradono Suryodiningrat \& Harco Leslie Hendric Spits Warnars; published by UIKTEN. This work is licensed under the Creative Commons Attribution-NonCommercial-NoDerivs 4.0 License.

The article is published with Open Access at https://www.temjournal.com/
Keywords - blended learning, framework, online learning, hybrid learning, blended learning framework, blended learning system.

\section{Introduction}

Online education is quickly becoming one of the main choices for higher level education students as it conveys many advantages on a global scale. Universities have been offering online courses because they are able to reach more students globally without having to resort to creating campuses all around the world. With the constant growth of information technology, the technology for online education is becoming even more accessible for everyone. Locally, there are some universities that offer online courses, however there is distinct lack of online education systems for upper secondary schools. This could be attributed to the difference in maturity between upper secondary school and university students where the latter are more likely to be actively pursuing their studies than the former. This leads to university students performing better than upper secondary students when exposed to online education. In the case when high school students are only exposed to e-learning without any classroom time, it was noted that some students are not capable and do not have the self-discipline to complete studies at their own time [1]. This leads to the notion that although online learning is a valuable tool, it cannot be a complete substitute to classroom learning. Because of the evolution of technology and internet technology, the foundation of anytime, anyplace learning program can be easily fulfilled [2].

Another aspect that could attribute towards the lack of online education systems in upper secondary schools is that through observation, universities are better financed than most upper secondary schools 
and as such would be able to invest in systems to support learning such as online education systems. However, as technology is rapidly advancing, the systems involved with online education are becoming more accessible to everyone. Which meant that upper secondary schools will be able to invest in online education systems which can help increase the quality of education that is being provided by the school. A simple online system can improve academic standards of a university simply by providing studying sources through an intranet which has found to increase the students focus on learning and getting them fully engaged to it [3].

With the creation of software such as Blackboard Collaborate, Zoom, Google Meet and other related synchronous communication software, it enables a learning environment like traditional classroom teaching where students are free to converse and ask questions at any time to their teachers. By applying some active learning strategies, it will encourage students to participate actively during their online study time [4]. However, regardless of the student's active participation, if the teachers are hard to reach and the course is poorly designed, then it will still be a detriment to the student's education [5]. As such, a complete support system will be needed for the students on top of a well-designed online and offline environment to ensure that students are successful in their studies.

After brief research, there have been several studies and journal articles written about "blended learning" which has shown to have more impact on upper secondary education students as it combines online teaching systems along with traditional classroom learning. With such system, it allows the student the freedom of autonomy during their online sessions as well as constant access to their materials online while still giving the students proper support and guidance through classroom learning. However, blended learning still has a very broad definition which leads to various interpretations of the system, but more will be discussed in the next section [6].

From the research, is shown that there has been limited trials of blended learning systems in developing country that can be applied to improve critical thinking skills and learning outcomes of students [7]. Although it has proven to be beneficial, most schools will require some guidance in order to achieve as much benefit as they can from blended learning.

\section{Methodology}

The author will use Design Science Research or DSR as the methodology (see Figure 1.). The DSR is a problem-solving paradigm and in the nutshell, it is the creation of innovative artifacts to solve real life problems [8]. It is a type of research that has to do with real life problems, and it is certainly not a theoretical type of research, and the main aim is to solve a problem. In DSR, there are 6 different sequential activities that can be shown in the DSR process model below.

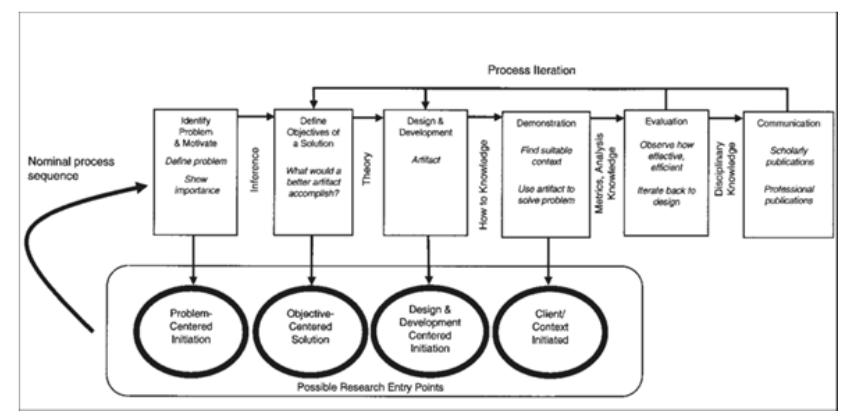

Figure 1. Design science research process model [9]

Activity 1 is the problem identification and motivation, which in this research paper is that online learning is having lots of challenges and it is even more challenging if it is implemented for upper secondary school students. But during this COVID19 pandemic, there are no other ways to conduct school other than online learning. Activity 2 is defining the objective for a solution, in this activity, the authors set the objective how to make online learning as effective as possible for upper secondary school. Activity 3 is design and development, at this activity, the artifact needs to be designed and developed to solve the identified problems and reach the objective(s). The artifact can be a prototype or a final product. Activity 4 is demonstration where it is the authors' responsibilities after the artifact has been made, it needs to be demonstrated to get feedbacks from any involved parties. Activity 5 is evaluation. While doing the demonstration, observation and measurement needs to be taken place to know whether the artifact is indeed solving the problem that is stated in activity 1 and reach the objective in activity 2. And the last is activity 6 , which is communication. At this activity, the authors need to communicate the problem and the artifact to the relevant audiences for further research.

\section{Problem Statement}

\subsection{Student Maturity}

Although not a large problem to overcome, student maturity is still a concern when establishing online program. Although there is an increase in students' performance over online programs, their lack of maturity means that when given free time or free study time, they have been found not to have been able manage their time properly as opposed to higher education students [1], [10]. While this may reduce 
the performance of some students, it can be alleviated through several means which will be discussed in the next section. Proposed in Australian vocational education and training, the 3 aspects that defined the readiness of online learning are, (1) students' preference, (2) the confident level of using electronic devices, and (3) the ability to engage in "auto-pilot" learning [11].

\subsection{Culture of Traditional Learning}

The culture of traditional learning in developing country (e.g., Indonesia) means that high school students are expected to understand the lessons given by teachers through a single learning session. While this method has been used for centuries, it limits independent learning as students are simply "spoon fed" of information rather than provoked into being inquisitive about studying. Through experience, most educators expect their word or education to be "taken as gospel" where students are expected to take it in and not ask questions about it. Traditional learning also means that students are still required to be present at school for learning and now there have not been many online learning systems being used in developing country. Most online systems being used are only to distribute additional class material or homework to the students.

\subsection{Courses and Curriculum}

The current courses and curriculum of the secondary school at its current state will not be able to support a blended learning system. It is a very dense study program with a very short time allowed for students to comprehend and understand the material. As such, most students will pursue tutoring from outside the school to catch up with materials that they don't understand or miss during their absences.

Blended learning requires that students are also given time for independent learning as the students would be encouraged to inquire rather than just accept the material that their educator gives them. But such cases depend on which model of blended learning is planned to be applied for the curriculum or course. The Theory of Knowledge which is applied at International Baccalaureate schools and extensive survey tools are potentially useful sources of information for creating a proper course or curriculum.

\subsection{Educator Preparedness}

Underneath the materials being given, the educator must also be properly prepared to teach in a blended learning system [5], [6], [12]. At the moment, developing country like Indonesia is suffering due to a lack of trained educators [13]. Without proper training and numbers, it will also affect the way blended learning is conducted and may prove more detrimental than beneficial for the student's studies [5].

\subsection{Infrastructure}

Conducting an online learning is getting easier and easier since the evolution of technology is rapidly growing. Now, cloud computing can be found everywhere and has been used in daily basis for supporting the daily activity. Cloud computing is a collation of interconnected computers that makes any application easily accessed from anywhere, and cloud computing has been used by public and private sector [14]. Since the cloud computing is getting more well-known and advanced, other technology is also evolving, such as the platform of Platform-as-aService or Software-as-a-Service is becoming popular and most of the application is moving towards using those technologies [15]. But unfortunately, not all schools know about this technology or how to use is properly.

\subsection{Need for Centralization}

Schools in developing country (e.g., Indonesia) are also disconnected from each other, they do not hold any influence over any other schools. The only connection they have is an annual meeting for teachers where they meet to discuss new learning methods as well as reporting the results of the existing ones. The only other time where they work together is the scheduling of final exams for secondary schools.

\section{Our Proposed Solutions}

An education system based on blended learning is not something new, however with the technology available today, it has great potential while being a proven method that can increase the quality of education for students. 
Table 1. Students cognitive test results [7]

\begin{tabular}{|c|c|c|c|c|}
\hline No & Student & Pre-Test & Post Test & Improvement \\
\hline 1 & $\mathrm{X} 2$ & 31 & 100 & 69 \\
\hline 2 & X18 & 39 & 100 & 61 \\
\hline 3 & X9 & 38 & 94 & 56 \\
\hline 4 & $\mathrm{X} 11$ & 36 & 88 & 52 \\
\hline 5 & $\mathrm{X} 20$ & 43 & 94 & 52 \\
\hline 6 & $\mathrm{X} 12$ & 51 & 100 & 49 \\
\hline 7 & $\mathrm{X} 1$ & 52 & 100 & 48 \\
\hline 8 & X29 & 32 & 80 & 48 \\
\hline 9 & X34 & 35 & 81 & 46 \\
\hline 10 & $\mathrm{X} 2$ & 36 & 80 & 44 \\
\hline 11 & $\mathrm{X} 4$ & 37 & 80 & 43 \\
\hline 12 & X32 & 38 & 80 & 42 \\
\hline 13 & $\mathrm{X} 16$ & 59 & 100 & 41 \\
\hline 14 & $\mathrm{X} 23$ & 41 & 80 & 39 \\
\hline 15 & X31 & 56 & 94 & 38 \\
\hline 16 & $\mathrm{X} 35$ & 56 & 94 & 38 \\
\hline 17 & X8 & 58 & 94 & 36 \\
\hline 18 & X33 & 65 & 100 & 35 \\
\hline 19 & X3 & 47 & 80 & 33 \\
\hline 20 & X19 & 55 & 88 & 33 \\
\hline 21 & X30 & 62 & 94 & 32 \\
\hline 22 & X17 & 64 & 94 & 30 \\
\hline 23 & $\mathrm{X} 10$ & 52 & 80 & 28 \\
\hline 24 & $\mathrm{X} 27$ & 52 & 80 & 28 \\
\hline 25 & $\mathrm{X} 7$ & 54 & 81 & 27 \\
\hline 26 & X24 & 61 & 88 & 27 \\
\hline 27 & X6 & 55 & 80 & 25 \\
\hline 28 & $\mathrm{X} 25$ & 55 & 80 & 25 \\
\hline 29 & $\mathrm{X} 13$ & 58 & 80 & 22 \\
\hline 30 & $\mathrm{X} 21$ & 68 & 88 & 20 \\
\hline 31 & $\mathrm{X} 22$ & 75 & 94 & 19 \\
\hline 32 & X14 & 63 & 81 & 18 \\
\hline 33 & $\mathrm{X} 5$ & 79 & 94 & 15 \\
\hline 34 & $\mathrm{X} 15$ & 73 & 80 & 7 \\
\hline \multirow[t]{3}{*}{35} & $\mathrm{X} 28$ & 77 & 80 & 3 \\
\hline & Sum & 1852 & 3081 & 1229 \\
\hline & Average & 52,9 & 88,0 & $66,36 \%$ \\
\hline
\end{tabular}

Table 1. above is based on a study group in Malang, Indonesia, and blended learning has proven to be beneficial in increasing students' capabilities [7]. The critical thinking skills of students have also increased significantly and as such it gives local proof that with careful planning, a blended learning system can benefit the education system [12].

\subsection{Blended Learning Framework}

We use Badrul's Khan Octagonal Framework (Figure 2.) as our base framework for blended learning. In the case for secondary schools, the pillars within the framework will help guide schools on what to focus on in order to establish a good blended learning system [16]. The strategy for the depth of blending will depend on the needs and goals of the school itself. Blending can be applied at different levels [6], such as by combining self-paced and live, collaborative learning. [12]. While this does not limit the schools to use the same blending for their education, it provides a starting point that will not require complete institution or curriculum revamp to support the blended learning system.

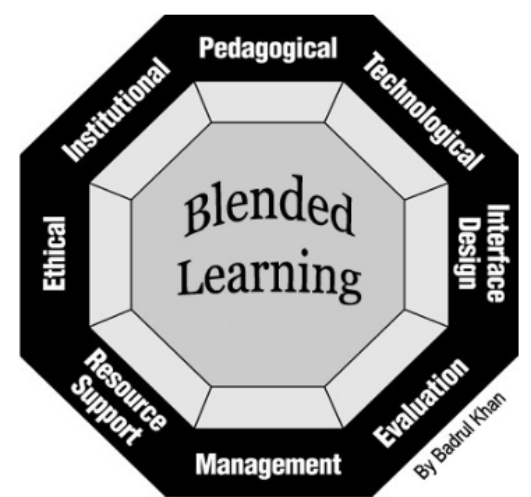

Figure 2. Khan's Octagonal Framework [16]

As discussed in the previous section, there are several issues that need to be addressed to apply blended learning for upper secondary schools. However, by going through the framework pillars, each issue will be addressed by the design of each pillar.

Beyond the framework, Table 2. also shows that beyond the framework and depth of blending there are 3 categories of blending, however for the purposes of developing blended learning system for upper secondary schools, using enhancing blends is suggested as it will not radically change the way teachers and students will interact on a day-to-day basis but rather seek to improve their current situation. It is also important to note that different schools will have different needs, which means that the blending of learning will depend on the strengths and weaknesses of each school. Table 3. from [6] shows the different strengths and weaknesses of each environment for study and should help each school understand what the proper choice for their system is.

Table 2. Categories of Blended Learning Systems adopted from [6]

\section{Enabling Blends}

\section{Enhancing Blends}

\section{Transforming} Blends
Mainly focus on solving the access and convenience issues. For example, blends that provide additional flexibility to all the learners and provide the same learning experience.

Changing of pedagogy but not drastically change the teaching and learning process for both online and offline. For example, give the same materials for both online and offline.

Blends that enable transformation of pedagogy radically. For example, adjust the learning materials and teaching activity that suitable for both offline and online 
Table 3. Strengths and weaknesses adopted from [6]

\begin{tabular}{|c|c|c|}
\hline & $\begin{array}{c}\text { Computer-Mediated } \\
\text { Environment } \\
\text { (Asynchronous Text- } \\
\text { Based Discussion) }\end{array}$ & $\begin{array}{c}\text { Face-to-Face } \\
\text { Environment (In- } \\
\text { Class Discussion) }\end{array}$ \\
\hline 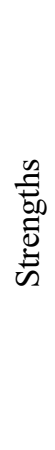 & $\begin{array}{l}\text { Flexibility - Students can } \\
\text { participate to any } \\
\text { discussions at any time and } \\
\text { any place. } \\
\text { Participation - Students } \\
\text { can participate without } \\
\text { being in the class } \\
\text { Depth of reflection - } \\
\text { Students will have more } \\
\text { time to have meaningful } \\
\text { reflection }\end{array}$ & $\begin{array}{l}\text { Human connection - } \\
\text { easier to bond and } \\
\text { social presence leads } \\
\text { developing trust } \\
\text { easier } \\
\text { Spontaneity - Easier } \\
\text { to have spontaneous } \\
\text { ideas and accidental } \\
\text { findings }\end{array}$ \\
\hline 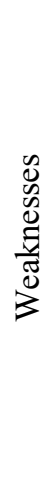 & $\begin{array}{l}\text { Spontaneity - It is difficult } \\
\text { to generate spontaneous } \\
\text { ideas and accidental } \\
\text { findings } \\
\text { Procrastination }- \text { High } \\
\text { possibility of } \\
\text { procrastination } \\
\text { Human connection - Due } \\
\text { to } 2 \text { different mediums, the } \\
\text { human connection is } \\
\text { relatively not as high as } \\
\text { face-to-face session. }\end{array}$ & $\begin{array}{l}\text { Participation }- \text { Not } \\
\text { everyone may } \\
\text { participate at the } \\
\text { same time, it } \\
\text { depends on the } \\
\text { personalities. } \\
\text { Flexibility - Limited } \\
\text { time that might } \\
\text { sacrifice the depth of } \\
\text { the discussion }\end{array}$ \\
\hline
\end{tabular}

With the chosen depth, category and blending chosen, the school is then ready to tackle the issue of establishing the pillars of the framework [16]. We described it in detail as follow:

\section{1) Institutional}

This pillar or dimension involves addressing all aspects around the whole education institute. Depending on the depth of blending, if the school wishes to implement blended learning from the institution level, they will dedicate their goals towards achieving this. Then they will have to ensure that all aspects of the institution are ready for such changes, starting from the admin personnel, student services, organization personnel and all the others need to be trained in order to support the new learning system.

\section{2) Pedagogical}

This pillar puts more concern on how best to provide the content and teach it to the students. As it is, the proven method for a school in Indonesia [17] is to use face to face classroom learning combined with an independent learning package or module where the students are expected to work and discuss the module online with their peers. This is categorized as an enhancing blend where it takes traditional face to face learning and enhances it by providing supplementary material online along with online guidance through several online means such as discussion forums, chat rooms, and social media. Again, the focus is to establish the best way to provide content as well as cater to the learners' needs and objectives.

\section{3) Technological}

This pillar addresses the needs of establishing the proper learning environment as well as providing the tools necessary to support it. While it can be assumed that most schools are already capable, it is better to mention the basics that a school will need to establish at least the capability to provide online face to face learning sessions as well as that it can provide additional material online. These include but no limited to a server to store student data for a centralized system with firewalls to protect it, Wireless connection for students to utilize, as well as a high-speed internet connection. When it comes to discussing the software that is planned to be used, there are many choices that the schools can choose from. Research [7] shows that students have successfully collaborated together in finishing online modules by communicating online using only Facebook and online discussion forum. While this does not mean one has to use the two methods of online communication, it is just a simple example that was proven to be effective.

\section{4) Interface design}

This pillar addresses the User Interface (UI) of the system. The UI of a system must be complicated enough to be able to cater to all the user needs, however it must be easy enough for the users to be able to access every of their materials with ease. On top of ease of use, the presentation of content is also important because if the users do not find the content or interface easy to use then the students will lose interest with the content and program.

\section{5) Evaluation}

This dimension is concerned with the proper evaluation of the blended learning system as well the performance evaluation of the students. The system should have a built in capability for evaluating both the previously mentioned points [16].

\section{6) Management}

This pillar deals with the management aspects of a blended learning system. A school needs to ensure that all management aspects of the program is on board with the implementation of the blended learning system.

\section{7) Resource support}

As mentioned by author [5], regardless of student performance if teachers are unreachable or content is 
unavailable then the students will have problems with their studies should they need these resources. Resource support deals with issues mentioned before, where the educator must ensure that there are teachers or tutors that can be contacted online easily as well as ensuring that additional materials are available to the student.

\section{8) Ethical}

Ethical aspects need to be addressed to ensure that there are no breaches. This framework is not meant as a hard guide where every pillar must be addressed to the letter, but it is meant as a soft guide where each pillar will help ensure that schools understand how blended learning needs to be established.

\subsection{Blended Learning for Upper Secondary Schools}

Curriculum or courses for a Blended learning system in upper secondary schools needs to ensure that it's able to address the issues of student maturity, the learning culture of the country, and educator preparedness. An enhanced blending system that builds upon the traditional classroom face to face learning by adding the availability of online material as well as tutors or teachers that can be contacted using synchronous communication will ensure that students will still be fully engaged while given some autonomy to exercise their active learning. The goal of having teachers that can be contacted online is to ensure that the students can be properly guided when they may get stuck with their online materials or independent studies. The blend of traditional face to face learning and online learning allows the students and educators to adapt to the online learning system while allowing them the comfort of traditional methods. This will lead to students and educators to be able to adjust slowly as it will not be a radical change to the previous single traditional classroom learning. Depending what level the blended learning is applied at, it will affect how the educator needs to prepare themselves and the curriculum or course for it. The educators must ensure that they are able to cope with the needs of the students. It is the educators' role to guide students in their learning while online by providing content and material that is both relevant and interesting in order keep their students actively learning

\subsection{Blended learning IT system}

IT Blueprint is needed before any education institution planned to implement or invest any IT equipment. The purpose of IT Blueprint is to analyze the business process that can support the teaching and learning better than before and better than traditional teaching and learning activities [18]. The IT Blueprint is also needed to increase the success of IT projects, since $50 \%-80 \%$ of the IT projects fail due to lateness, over budget, below expectation, and not fulfilling the needed requirements [19]. The IT Blueprint framework that the education institution must follow is as shown in Figure 3.

A blended learning system requires both synchronous and asynchronous systems to be prepared by the schools to ensure that all materials and teachers are easy to access and contact. Assuming a school is already IT capable where they already have computer system and network that allows them to store student's data and work along with being able to host materials for students to download. Along with a high-speed internet connection which will allow teachers or tutors to be contacted using synchronous communication with ease.

To be able to provide a learning environment like a traditional classroom, it may be suggested that schools and educators use software such as Blackboard Collaborate, Zoom, Google Meet and other related software. However, it must be considered carefully that not all students will have access to systems or computers that will be able to support the various software. However, Stanford University is developing an interactive online lecture viewing system called ClassX [17]. This software is an excellent alternative to the other mentioned software as it has a very low system requirement, it only requires users to install Microsoft Silverlight on top of most browsers. This low system requirement is what makes this software an attractive alternative to most other synchronous communication systems.

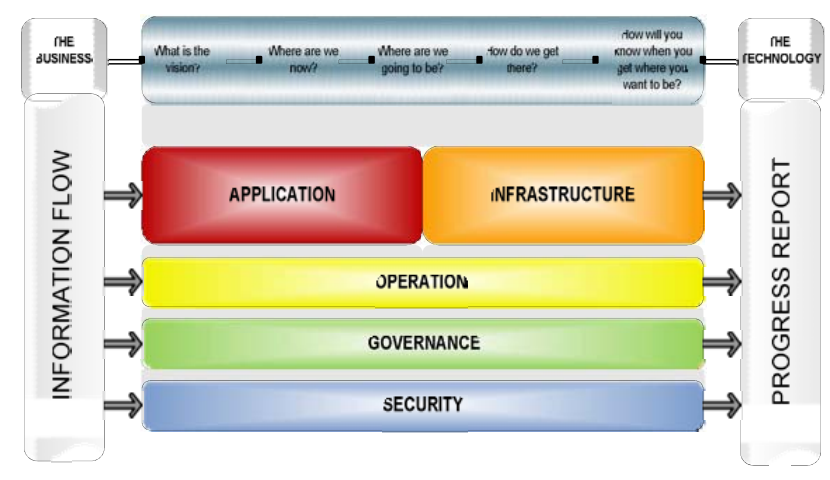

Figure 3. IT Blueprint framework [18]

In terms of hardware, technology today allows access to several services that alleviates much of the costs of establishing some systems such as servers by using cloud services. Security on such systems is already considered very secure without having to dedicate additional hardware or software for it. The availability and evolution of cloud computing, IaaS, PaaS, and SaaS, makes the implementation of online learning become easier because of the flexibility and support heavy demand [20]. 


\section{Recommendations}

The solutions provided are using the best practice based on research, however it may not be the best choice at all. Each school will have to apply the blended learning systems and styles that best suit their institution. The IT Blueprint needs to be followed and revisited every 3-5 years, there might be some adjustment due to situation and condition in internally and externally. When IT Blueprint is being developed and followed, the transition matrix needs to be monitored to make sure that the IT transition is on schedule (Figure 4.).

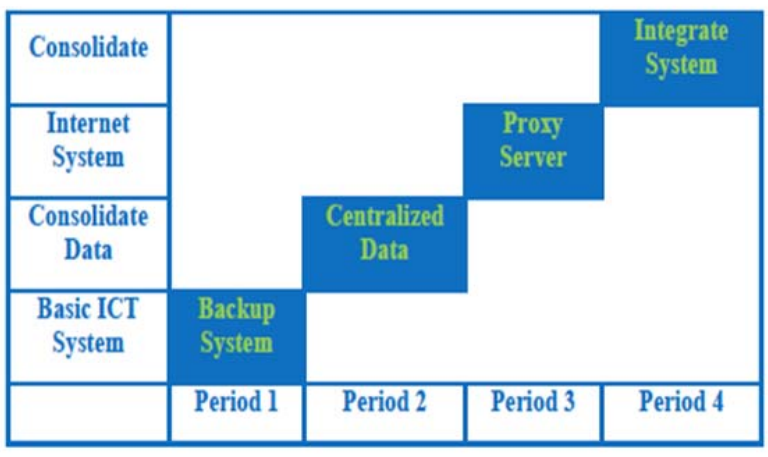

Figure 4. Transition matrix

In the future, it is recommended that a centralization of the education system be considered as it will allow the government to be able to monitor closely and help regulate the education system. It would also address the concern of security when it comes to exam questions as the government can just distribute said questions through the online system where it will limit the exposure of the questions and potentially limit the incidents where the questions leak to the public prior to exams. In addition to centralizing the system, it is also recommended that further research is done to investigate implementing a blended learning system into a nationwide network to streamline nationwide education.

\section{Conclusion}

Blended learning is becoming a very attractive alternative for enriching a studying environment. The advance of technology allows for much better options for implementing blended learning. On top of that, there are now more researches that have proven that blended learning is superior to traditional methods of teaching.

The framework, curriculum, and IT recommendations in this document will help schools design and implement blended learning systems. While there is no single best solution, the framework in this document will help education institutions to prepare a solution that is best suited for their needs.

\section{Acknowledgments}

This work is supported by the Research and Technology Transfer Office, Bina Nusantara University as a part of Bina Nusantara University's International Research Grant contract number: No.017/VR.RTT/III/2021 contract date: 22 March 2021.

\section{References}

[1]. Zhang, D., Zhao, J. L., Zhou, L., \& Nunamaker Jr, J. F. (2004). Can e-learning replace classroom learning?. Communications of the ACM, 47(5), 75-79.

[2]. Picciano, A. G., Seaman, J., Shea, P., \& Swan, K. (2012). Examining the extent and nature of online learning in American K-12 education: The research initiatives of the Alfred P. Sloan Foundation. The internet and higher education, 15(2), 127-135.

[3]. Adeyeye, O. M., Afolabi, I. T., \& Ayo, C. K. (2014). Virtual learning in Nigerian universities: A panacea for enhanced academic standards. International Journal for Innovation Education and Research, 2(2), 40-49.

[4]. Phillips, J. M. (2005). Strategies for active learning in online continuing education. The Journal of Continuing Education in Nursing, 36(2), 77-83.

[5]. Barbour, M., Siko, J., Sumara, J., \& Simuel-Everage, K. (2012). Narratives from the Online Frontier: A K12 Student's Experience in an Online Learning Environment. The Qualitative Report, 17(10), 1-19.

[6]. McGrath, V. (2007). The handbook of blended learning: Global perspectives, local designs memorial. Canadian Journal of University Continuing Education, 33(1).

[7]. Pratiwi, H. E., Suwono, H., \& Handayani, N. (2014). Pengembangan Modul Pembelajaran Biologi Berbasis Hybrid Learning untuk Meningkatkan Kemampuan Berpikir Kritis dan Hasil Belajar Siswa Kelas XI. Jurnalonline. Um. Ac. Id, 1-12.

[8]. Hevner, A., \& Chatterjee, S. (2010). Introduction to design science research. In Design Research in Information Systems (pp. 1-8). Springer, Boston, MA.

[9]. Peffers, K., Tuunanen, T., Rothenberger, M. A., \& Chatterjee, S. (2007). A design science research methodology for information systems research. Journal of management information systems, 24(3), 45-77.

[10]. Lowes, S. (2005). Online teaching and classroom change: The impact of virtual high school on its teachers and their schools. New York: Institute for Learning Technologies, Columbia University

[11]. Hung, M. L., Chou, C., Chen, C. H., \& Own, Z. Y. (2010). Learner readiness for online learning: Scale development and student perceptions. Computers \& Education, 55(3), 1080-1090.

[12]. Murphy, E., Rodríguez-Manzanares, M. A., \& Barbour, M. (2011). Asynchronous and synchronous online teaching: Perspectives of Canadian high school distance education teachers. British Journal of Educational Technology, 42(4), 583-591.

[13]. Rohman, M. (2016). Problematika Guru dan Dosen dalam Sistem Pendidikan di Indonesia. Cendekia: Jurnal Kependidikan Dan Kemasyarakatan,14(1), 49-71. 
[14]. Siddiqui, S. T., Alam, S., Khan, Z. A., \& Gupta, A. (2019). Cloud-based e-learning: using cloud computing platform for an effective e-learning. In Smart Innovations in Communication and Computational Sciences (pp. 335-346). Springer, Singapore.

[15]. Singh, A., Sharma, S., Kumar, S. R., \& Yadav, S. A. (2016, February). Overview of PaaS and SaaS and its application in cloud computing. In 2016 International Conference on Innovation and Challenges in Cyber Security (ICICCS-INBUSH) (pp. 172-176). IEEE.

[16]. Singh, H. (2021). Building effective blended learning programs. In Challenges and Opportunities for the Global Implementation of E-Learning Frameworks (pp. 15-23). IGI Global.

[17]. Mavlankar, A., Agrawal, P., Pang, D., Halawa, S., Cheung, N. M., \& Girod, B. (2010, December). An interactive region-of-interest video streaming system for online lecture viewing. In 2010 18th International packet video workshop (pp. 64-71). IEEE.
[18]. Astriani, M. S., \& Pradono, S. (2011, December). IT blueprint and school. In Proceedings of the 10th WSEAS international conference on Computational Intelligence, Man-Machine Systems and Cybernetics, and proceedings of the 10th WSEAS international conference on Information Security and Privacy (pp. 160-167).

[19]. Astriani, M. S., Pradono, S., \& Saragih, H. (2010, December). IT blueprint for education institution. In 2010 Second International Conference on Advances in Computing, Control, and Telecommunication Technologies (pp. 180-184). IEEE.

[20]. Doelitzscher, F., Sulistio, A., Reich, C., Kuijs, H., \& Wolf, D. (2011). Private cloud for collaboration and e-Learning services: from IaaS to SaaS. Computing, 91(1), 23-42. 